\title{
Sengketa Wilayah Zona Ekonomi Eksklusif Indonesia (Studi Kasus Klaim Cina Atas Laut Natuna Utara)
}

\author{
Ririn Ardila*; Akbar Kurnia Putra \\ Fakultas Hukum, Universitas Jambi \\ *Coresponding author: ririnardila98@gmail.com \\ Submission : 30 Juli 2020 \\ Revision : 31 Oktober 2020 \\ Publication : 23 November 2020
}

\begin{abstract}
Natuna Utara Sea is the Exclusive Economic Zone of Indonesia which is located in the Riau Islands Province, namely Natuna District. the emergence of territorial dispute in the Natuna Utara Sea due to Cina's claim on to nine-dash line. This research discusses whether Cina's claim of the nine-dash line over the North Natuna Sea complies with the 1982 UNCLOS provisions and examines Indonesia's attitude towards Cina's claims in the North Natuna Sea. The type of research used is Normative with statue approach, historical approach, and case law approach. The results of the study conclude that Cina's claims on the nine-dash line against theNatuna Utara Sea are contradictory and irrelevant according to UNCLOS 1982 and Indonesia considers that Indonesia does not have any disputes with Cina.
\end{abstract}

Keywords: Cina; Natuna Utara Sea; Nine-Dash Line

\begin{abstract}
Abstrak
Laut Natuna Utara merupakan Zona Ekonomi Eksklusif Indonesia yang terletak di Provinsi Kepulauan Riau yaitu Kabupaten Natuna, timbulnya sengketa wilayah di Laut Natuna Utara karena adanya Klaim Cina terhadap nine-dash line atau sembilan garis putus-putus. Penelitian ini membahas tentang apakah klaim nine-dash line atas laut Natuna Utara oleh Cina sesuai dengan ketentuan UNCLOS 1982 dan mengkaji bagaimana sikap Indonesia terhadap klaim negara
\end{abstract}


Cina di laut Natuna Utara. Jenis Penelitian yang digunakan adalah Normatif dengan pendekatan perundang-undangan (statue approach), pendekatan sejarah (historical approach), dan pendekatan kasus (case law approach). Hasil penelitian menyimpulkan bahwa klaim Cina atas nine-dash line terhadap laut Natuna Utara bertentangan dan tidak Relevan menurut UNCLOS 1982 dan Indonesia beranggapan bahwasannya Indonesia tidak memiliki sengketa apapun dengan Cina.

Kata Kunci: Tiongkok; Laut Natuna Utara; Nine-dash Line

\section{A. Pendahuluan}

Unsur berdirinya suatu negara diatur pada pasal 1 Montevideo (Pan American) Convention On Rigths and Duties Of States Of 1933 Yang salah satunya adalah a defined territory yang artinya untuk berdirinya suatu negara harus adanya suatu wilayah, baik itu wilayah daratan, udara maupun wilayah laut. ${ }^{1}$ Wilayah laut cenderum lebih besar dibumi jika dibandingkan dengan wilayah daratan terlihat dalam kondisi geografis bumi wilayah lautan menduduki $3 / 4$ atau sekitar $70 \%$ dari total wilayah permukaan bumi. ${ }^{2}$ Mengenai Wilayah laut sudah diatur secara gamlang oleh United Nations On The Law Of The Sea 1982, wilayah laut terdiri dari perairan pedalaman, laut teritorial, perairan negara kepulauan, zona tambahan, zona ekonomi eksklusif, landasan kontinen, laut bebas, Kawasan dasar laut teritorial.

Kerap terjadi problematika diwilayah laut, misalnya status wilayah serta batas-batas Negara seperti negara bertetangga, persoalan inilah yang menjadi salah satu faktor persengketaan antar negara, Padahal persengketaan antar negara dapat memengaruhi kepentingan vital negara seperti

${ }^{1}$ Ni'matul Huda. Ilmu Negara. Jakarta :Penerbit Raja Wali Pers. 2014. hal. 17.

2 Alief Sambago. Penamaan Laut Natuna Utara Oleh Pemerintah Indonesia Dalam Perspektif Hukum Internasional. Jurist-Diction. Vol.1 No. 2. hal. 382. 
halnya integritas wilayah. Persoalan mengenai batas-batas wilayah laut sebenernya penetapan batas wilayah laut sudah diatur didalam hukum laut internasional atau UNCLOS 1982, seperti pengaturan mengenai batas wilayah laut pada Zona Ekonomi Eksklusif pada pasal 57 yang menyatakan "The exclusive economic zone shall not extend beyond 200 nautical miles from the baselines from which the breadth of the territorial sea is measured"3 Yang artinya Zona Ekonomi Eksklusif tidak boleh melebihi 200 Mil laut dari garis pangkal dari mana lebar laut teritorial diukur.

Negara Republik Indonesaia sudah meratifikasi UNCLOS 1982 pada tahun 1985 dengan Undang-Undang Nomor 17 Tahun $1985^{4}$ yang telah menjadikan UndangUndang Nomor 5 tahun $1983^{5}$ yang mengatur lengkap mengenai Zona Ekonomi Eksklusif Indonesia. Sebagai negara peserta yang telah meratifikasi UNCLOS 1982 maka Indonesia berhak menarik garis zona ekonomi eksklusif sejauh $200 \mathrm{Mil}$, penarikan tersebut sampailah ke Laut Natuna Utara yang terletak di Provinsi Kepulauan Riau, yaitu Kabupaten Natuna yang berada pada posisi 10016'-7019' Lintang Utara dan 1050 00'-110000' Bujur Timur dan berbatasan dengan negara Vietnam dan Kamboja. ${ }^{6}$ Tak hanya Vietnam dan Kamboja bahkan laut Natuna Utara juga berbatasan dengan Laut Cina Selatan. Berbicara mengenai laut Cina Selatan, selain Indonesia ada beberapa negara juga yang berbatasan dengan Laut Cina Selatan salah satunya Cina.

3 Pasal 57 United Nations Conventions On The Law Of The Sea 1982.

${ }^{4}$ Undang-UndangNomor 17 Tahun 1985 Tentang pengesahan United Nations Conventions On The Law Of The Sea 1982

5 Undang-Undang Nomor 5 Tahun 1983 Tentang Zona Ekonomi Eksklusif Indonesia.

${ }^{6}$ Pemerintahan Kabupaen Natuna. https://natunakab.go.id/sela yang- panadang- kabupaten -natuna-provinsi -kepulauan -riau/. Diakses pada tanggal 13 Juni 2020. 
Dengan adanya penarikan garis ZEEI sejauh $200 \mathrm{mil} \mathrm{di}$ laut Natuna Utara, kemudian timbul pelanggaran yang mana Cina telah lama mengklaim nine-dash line atau sembilan garis putus-putus kebeberapa negara yang berbatasan dengan Laut Cina Selatan, kemudian garis tersebut menjorok masuk ke ZEEI Indonesia. Kapal Cina masuk ke Zona Ekonomi Eksklusif Indonesia ${ }^{7}$ yakni Laut Natuna Utara Pada tanggal 23 desember 2019 dan mengklaim nine-dash line.

Penelitian ini bertujuan untuk mengkaji apakah klaim nine-dash line atas laut Natuna Utara oleh Cina sesuai dengan ketentuan UNCLOS 1982 dan Mengetahui bagaimana sikap Indonesia terhadap klaim negara Cina di laut Natuna Utara.

\section{B. Metode Penelitian}

Penelitian ini merupakan penelitian hukum yuridis normative. Menurut Peter Mahmud Marzuki Penelitian hukum normatif adalah penelitian kepustakaan yang meneliti bahan Pustaka, dengan mempelajari sumber-sumber atau bahan tertulis berupa buku-buku, artikel, koran, dan majalah, ${ }^{8}$ dengan menerapkan beberapa pendekatan, yaitu dengan menggunakan pendekatan perundang-undangan (statue approach), pendekatan sejarah (historical approach), dan pendekatan kasus (case law approach).

\section{Pembahasan}

7 Menurut Pasal 2 Undang-Undang Nomor 5 tahun 1983 Zona ekonomi eksklusif Indonesia adalah jalur diluar dan berbatasan dengan laut wilayah Indonesia sebagaiman aditetapkan berdasarkan undang-undang yang berlaku tentang perairan Indonesia yang meliputi dasar laut, tanah dibawahnya dan air diatasnya dengan batas terluar 200 (dua ratus) mil laut diukur dari garis pangkal laut wilayah Indonesia.

8 Peter Mahmud Marzuki. Penelitian Hukum. Penerbit Kencana, Jakarta. 2008. Hal. 93. 


\section{Klaim nine-dash line atas laut Natuna Utara oleh Cina menurut Ketentuan United Nations Conventions On The Law Of The Sea 1982.}

Laut Natuna Utara merupakan wilayah Zona Ekonomi Eksklusif Indonesia yang terletak di Provinsi Riau, Kabupaten Natuna. Laut Natuna utara berbatasan dengan laut Cina Selatan, tidak hanya negara Indonesia saja yang berbatasan dengan laut Cina Selatan melainkan negara lain seperti Cina, Taiwan, Vietnam, Kamboja, Thailand, Malaysia, Singapura, Brunei Darusalam, dan Filiphina. Laut Cina Selatan kerap menjadi problematika diantara beberapa negara yang berbatasan seperti Cina, Cina telah lama mengklaim nine-dash line atau sembilan garis putus-putus di Laut Cina Selatan.

Cina mengklaim hampir seluruh wilayah perairan di Laut Cina Selatan sebagai wilayah teritorialnya9 ${ }^{9}$, klaim ini merupakan peta Sembilan Garis Putus-putus (Nine-Dash Line) yang dibuat oleh Cina ini berdasarkan fakta sejarah masa lampau bangsa Cina yang telah lama meyakini bahwa wilayah Laut Cina Selatan merupakan wilayah mereka. Sengketa kepemilikan kedaulatan teritorial di Laut Cina Selatan sesungguhnya merujuk kepada wilayah kawasan laut dan daratan didua gugusan kepulauan Paracel dan Spratly.10 Namun permasalahannya adalah klaim yang dilakukan oleh Cina atas nine-dash line ini menjorok masuk kedalam Zona ekonomi eksklusif Indonesia yakni Laut Natuna Utara.

Fakta sejarah kuno ini bermula pada abadke 2 sebelum masehi, Menurut Cina pulau dan wilayah Laut Cina Selatan

9 Menurut black's law dictionary klaim adalah Claim To demand as one's own; to state; to urge; to insist, yang terjemahan bebasnya adalah mengklaim menuntut sebagai milik sendiri; untuk menyatakan; untuk mendesak; untuk bersikeras.

10 Muhar Junef. Sengketa Wilayah Maritim Di Laut Tiongkok Selatan Maritime Territorial Dispute in South Cina Sea. De Jure. Vol. 18. No. 2. hal. 220. 
ditemukan oleh pendahulu Cina, kepulauan tersebut yang mempunyai alasan kepemilikan Pulau Paracel (Pulau Hainan) dan peninggalan sejarah yang konon berasal dari Dinasti Han sejak abad ke 2 sebelum masehi, kemudian pada abad 12 sebelum masehi pulau-pulau dan wilayah laut Laut Cina Selatan di masukkan oleh negara Cina kedalam peta teritori Cina oleh Dinasti Yuan, berlanjut pada abad ke 13 sebelum Masehi Cina meyakini nine-dash line tersebut karena diperkuat dengan adanya Dinasti Ming dan Dinasti Qing pada abad ke 13 sebelum masehi.

Kemudian pada tahun 1947 Cina memproduksi peta Laut Cina Selatan dengan Sembilan garis putus-putus yang membentuk huruf $U$, serta menyatakan semua wilayah yang ada di dalam di garis merah putus-putus tersebut adalah wilayah teritorial Cina. Klaim nine-dash line yang dilakukan oleh Cina tersebut membuat salah satu negara yang berbatasan dengan laut Cina Selatan tidak tinggal diam. Negara Philipina yang termasuk dalam klaim tersebut membawa sengketa ini pada Permanent Court of Arbitration (PCA). Permanent Court Of Arbitration (PCA) merupakan badan arbitrase yang menyelesaikan sengketa antar negara yang sudah berdiri sejak lama dan memiliki hukum acaranya yang terletak di Den Haag Belanda. ${ }^{11}$

Philipina mengajukan sengketa tersebut pada tanggal 22 Januari 2013, putusan dari sengketa tersebut keluar pada tanggal 12 Juli 2016. Hasil putusan yang dikeluarkan oleh PCA adalah sebagai berikut :

"The Tribunal concludes that, as between the Philippines and Cina, Cina's claims to historic rights, or other sovereign rights or jurisdiction, with respect to the maritime areas of the South Cina Sea encompassed by the relevant part of the 'nine-dash line' are contrary

11 Huala Adolf. Hukum Penyelesaian Sengketa Internasional. Sinar Grafika, Jakarta. 2016. hal. 40. 
to the Convention and without lawful effect to the extent that they exceed the geographic and substantive limits of Cina's maritime entitlements under the Convention. The Tribunal concludes that the Convention superseded any historic rights or other sovereign rights or jurisdiction in excess of the limits imposed therein"12

Jika diterjemah bebaskan dalam Bahasa Indonesia arti dari putusan tersebut adalah: Pengadilan menyimpulkan bahwa, antara Filipina dan Cina, klaim Cina atas hak bersejarah, atau hak kedaulatan atau yurisdiksi lainnya, sehubungan dengan wilayah maritim Laut Cina Selatan yang dicakup oleh bagian yang relevan dari sembilan garis putus-putus adalah bertentangan dengan Konvensi dan tanpa efek yang sah sejauh mereka melebihi batas geografis dan substantif dari hak maritim Tiongkok berdasarkan Konvensi. Pengadilan menyimpulkan bahwa Konvensi menggantikan hak bersejarah atau hak kedaulatan atau yurisdiksi lain yang melebihi batas yang diberlakukan di dalamnya

Walaupun PCA sudah mengeluarka nhasilputusan yang sudahdi jelaskan diatas, namun pihak Kementrian Luar Negeri Cina mengeluarkan pernyataan terkait hasil putusan yang dikeluarkan oleh PCA, pernyataan tersebut adalah sebagai berikut :

"The ruling is null and void with no binding force. It will in no way affect Cina's territorial sovereignty and maritime rights and interests in the South Cina Sea. We oppose and refuse to accept any proposal or action based on the ruling. Cina will continue to safeguard territorial sovereignty and maritime rights and interests, maintain peace and stability in the South Cina Sea, and endeavor to peacefully resolve relevant disputes in the South Cina Sea with parties directly concerned through negotiation and consultation on the

12 The South Cina Sea Arbitration Award Paragraf 278.

Uti Possidetis: Journal of International Law, Vol. 1, No. 3 (2020) 
basis of respecting historical facts and in accordance with international law."13

Yang artinya Keputusan itu batal demi hukum tanpa kekuatan mengikat. Ini sama sekali tidak akan memengaruhi kedaulatan teritorial Cina dan hak serta kepentingan maritim di Laut Cina Selatan. Kami menentang dan menolak untuk menerima proposal atau tindakan berdasarkan putusan tersebut. Cina akan terus menjaga kedaulatan teritorial dan hak serta kepentingan maritim, menjaga perdamaian dan stabilitas di Laut Cina Selatan, dan berusaha untuk menyelesaikan secara damai sengketa yang relevan di Laut Cina Selatan dengan pihak-pihak terkait secara langsung melalui negosiasi dan konsultasi atas dasar penghormatan terhadap fakta sejarah. dan sesuai dengan hukum internasional.

Selanjutnya Cina masih tetap mengklaim Nine-Dash Line, kemudian pada tanggal 23 desember 2019 kapal Negara Cina masuk kedalam Zona Ekonomi Eksklusif Indonesia di Laut Natuna Utara dan Kembali mengklaim nine-dash line, seperti yang sudah dijelaskan dipembahasan Cina juga mengatakan tidak seharusnya nelayan Cina ditangkap oleh KKP karena mereka hanya melakukan kegiatan traditional fishing ground. Sebenarnya ini bukan kali pertama Cina memasuki ZEEI, Cina masuk dan mulai mengklaim di ZEEI pada tanggal 16 juni. Sebenarnya Cina memang tidak masalah jika masuk dan berlayar di ZEEI, yang jadi permasalahannya adalah Cina memasuki ZEEI selain mengklaim Nine-dash line pada saat itu Cina juga melakukan kegiatan Ilegal Fishing. Jika berbicara secara History dan secara hukum laut Internasional kepemilikan laut Natuna utara adalah milik Indonesia.

13 Foreign Ministry Spokesperson Lu Kang's Remarks on Statement by Spokesperson of US State Department on South Cina Sea Arbitration Ruling, https://www.fmprc.gov.cn/nanhai/eng/ fyrbt 1/t1380409.htm. Diakses pada Tanggal 21 Oktober 2020.

Uti Possidetis: Journal of International Law, Vol. 1, No. 3 (2020) 


\section{Sejarah laut Natuna Utara}

Laut Natuna Utara merupakan laut yang berbatasan dengan Laut Cina Selatan. Laut Cina Selatan merupakan zona laut bebas yang berada di selatan Cina dengan titik koordinat $4^{\circ} 48^{\prime}$ Lintang Utara - $108^{\circ} 01^{\prime}$ Bujur Timur dari utara kepulauan Natuna milik negara republik Indonesia. laut Cina Selatan bersinggungan dengan batas-batas Zona ekonomi eksklusif dibeberapa negara yaitu di Asia Tenggara, Malaysia dan Vietnam disebelah barat dan barat daya, Filipina di timur, Brunei Darussalam serta Malaysia disebelah tenggara dan Indonesia disebelah selatan.

Laut Cina Selatan sendiri merupakan Laut Bebas yang berbatasan dengan negara-negara lain, pada saat itu laut Natuna Utara masih bernama laut Cina Selatan, nama laut Cina selatan diambil, digunakan, dan disepakati karena memudahkan penyebutan nama di wilayah laut bebas di selatan Cina, karena pada jaman itu banyak negara di ASEAN belum merdeka sepenuhnya sehingga akan rumit apabila harus menamai dengan nama daerah yang masih dalam masa penjajahan. Nama ini telah disepakati dalam dokumen S-23 IHO yang diterjadi pada tahun 1953, Dalam dokumen S-23 telah disepakati penamaan wilayah laut bebas di selatan Cina sebagai Laut Cina Selatan, hal itu pula yang membuat Cina beranggapan bahwa wilayah tersebut merupakan hak milik mereka dan Cina memiliki kedaulatan untuk melakukan ekplorasi dan eksploitasi di wilayah Laut Cina Selatan. ${ }^{14}$

Dilihat secara historis, Laut Cina Selatan merupakan wilayah yang berpotensi dilanda konflik karena berbatasan dan bersinggungan langsung dengan batas-batas zona ekonomi eksklusif negara-negara di Asia Tenggara maupun negara Asia Muka seperti Cina dan Jepang maka dari itu

14 Alief Sumbago. Penamaan Laut Natuna Utara Oleh Pemerintah Indonesia Dalam prespektif Hukum Internasional. Juris-diction. Vol 1. No 2. hal. 389. 
Indonesia melakukan Pembenanahan peta wilayah Indonesia yang dilakukan oleh pemerintah Indonesia adalah penegasan batas-batas zona maritim di daerah Natuna Utara yang bersinggungan dengan Laut Cina Selatan. Kemudian Pada tahun 1957, kepulauan Natuna awalnya masuk dalam wilayah Kerajaan Petani dan Kerajaan Johor di Malaysia. Namun pada abad ke 19, kepulauan Natuna akhirnya masuk kedalam penguasaan Kesultanan Riau dan menjadi wilayah dari Kesultanan Riau, dimana kepulauan Natuna berada di jalur strategis dari pelayaran internasional. Setelah Indonesia merdeka, Delegasi dari Riau ikut menyerahkan kedaulatan pada Republik Indonesia yang berpusat di Pula Jawa. Pada 18 Mei 1956, pemerintah Indonesia resmi mendaftarkan kepulauan Natuna sebagai wilayah kedaulatan ke Perserikatan Bangsa-Bangsa (PBB).

Selanjutnya pada tahun 2017 pemerintah Indonesia tentunya dibawah arahan Presiden Joko Widodo adalah memperbaharui peta nasional hal ini merupakan tindakan yang positif dan berani untuk menjamin hak berdaulat, keamanan, dan kepastian hukum bagi negara Indonesia. Penegasan batas-batas wilayah yang telah disepakati bersama negara-negara tetangga membuat wilayah Indonesia memiliki kedaulatan dan hak berdaulat yang diakui di dunia internasional. Perubahan nama Laut Cina Selatan menjadi Laut Natuna Utara merupakan salah satu langkah politik terbaik yang dilakukan Indonesia guna menegaskan bahwa Indonesia tidak berpihak pada negara yang melakukan klaim tanpa dasar dan sesuai dengan United Nations Convention On The Law Of The Sea 1982.

Dalam penarikan garis zona ekonomi eksklusif 15 yang dilakukan oleh Indonesia sesuai dengan aturan yang dimuat

15 Menurut pasal 55 United Nations Conventions One The law Of The Sea 1982 Zona ekonomi eksklusif adalah suatu daerah di luar dan 
dalam pasal 57 UNCLOS 1982 yaitu : "The exclusive economic zone shall not extend beyond 200 nautical miles from the baselines from which the breadth of the territorial sea is measured"16 dalam ketentuan ini Indonesia berhak menarik garis zona ekonomi eksklusif sejauh 200 Mil.

\section{Klaim Cina terhadap Nine-dash line di laut Natuna Utara}

Klaim Cina atas zona ekonomi eksklusif Indonesia di laut Natuna Utara kedalam Sembilan Garis Putus-putus Cina merupakan bentuk arogansi Cina yang ingin menguasai penuh wilayah Laut Cina Selatan tersebut. ${ }^{17}$ Klaim nine-dash line dilaut Natuna Utara merupakan klaim atas sembilan garis putus-putus yang berbentuk seperti lidah atau huruf $U$ dan diakui sebagai hak maritim Cina dan telah dipercaya masyarakat Cina sejak lama.

Berikut ini adalah gambar visualisasi nine-dash line atau sembilan garis putus-putus yang diklaim oleh negara Cina: ${ }^{18}$

berdampingan dengan laut teritorial, yang tunduk pada rejim hukum khusus yang ditetapkan dalam Bab ini berdasarkan mana hak-hak dan yurisdiksi Negara pantai dan hak-hak serta kebebasan-kebebasan Negara lain, diatur oleh ketentuanketentuan yang relevan Konvensi ini.

16 Terjemahan bebas : Zona ekonomie eksklusif tidak boleh melebihi 200 mil laut dari garis pangkal darimana lebar laut teritorial diukur.

17 Fitra Deni dan Lukman Sari. Upaya Diplomasi Indonesia Terhadap Klaim Cina Atas Zona Ekonomi Eksklusif Indonesia Di Laut Natuna Utara. International \& Diplomacy, Vol. 3. No. 1. hal. 5.

18 Hikmahanto Juwana. Kepatuhan Negara Terhadap Hukum Internasional: Putusan PCA Atas Laut Cina Selatan. Jambi : Seminar Hukum Internasional Universitas Jambi. 2019. Hal. 11.

Uti Possidetis: Journal of International Law, Vol. 1, No. 3 (2020) 368 


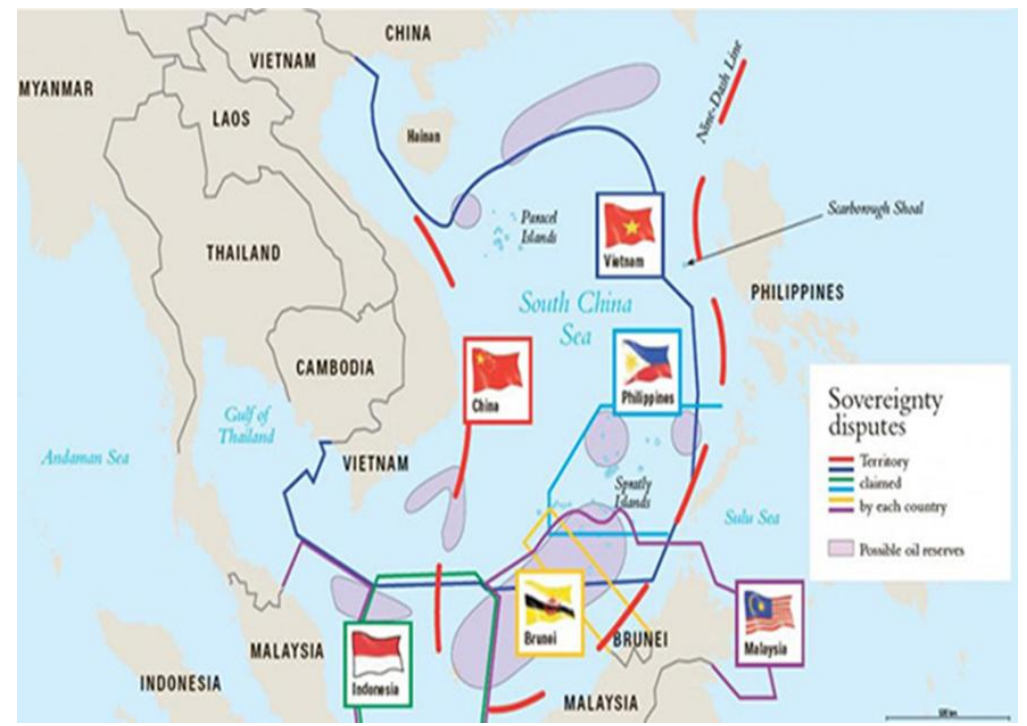

Direktur Studi Perbatasan Cina yaitu Li Guo qiang mengatakan: "Ada seluas $50.000 \mathrm{~km} 2$ wilayah tumpang tindih antara klaim Cina atas nine-dash line dengan Zona Ekonomi Eksklusif Indonesia"19 Dengan ini jelas bahwa Klaim Cina terhadap nine-dash line di laut Natuna Utara tidak sesuai dengan ketentuan hukum laut internasional atau UNCLOS 1982.

Jika dikaji dalam hukum laut Internasional lebar laut teriorial sendiri diatur pada pasal 3 UNCLOS $1982^{20}$ yang menyatakan "Every State has the right to establish the breadth of its territorial sea up to a limit not exceeding 12 nautical miles, measured from baselines determined in accordance with this Convention."21 Pada pasal tersebut menjelaskan bahwa setiap

19 Batamnews, https:// www. Batamnews .co.id/ berita- 141168mengenal -9-garis- putus putus- tiongkok- dan- klaim- Cinaselatan.html. Diakses pada tanggal 21 Agustus 2020.

20 Pasal 3 United Nations Conventions On The Law Of The Sea 1982.

21 Terjemahan bebas: Setiap Negara mempunyai hak untuk menetapkan lebar laut teritorialnya sampai suatu batas yang tidak melebihi 12 mil laut, diukur dari garis pangkal yang ditentukan sesuai dengan Konvensi ini.

Uti Possidetis: Journal of International Law, Vol. 1, No. 3 (2020) 
negara berhak menarik garis laut teritorialnya sejauh 12 mil, selanjutnya dalam hal ini negara pantai mempunyai kedaulatan atas laut teritorialnya tersebut dan dalam pelaksanaannya kedaulatan atas laut teritorial ini tunduk pada ketentuan hukum internasional.22 Pada pasal tersebut menjelaskan bahwa setiap negara berhak menarik garis laut teritorialnya sejauh 12 mil, berarti Klaim Cina terhadap Ninedash line atas laut Natuna Utara sudah melanggar pasal 3 UNCLOS 1982 karena garis yang ditarik oleh negara Cina melebihi ketentuan yang telah diatur oleh UNCLOS 1982, Cina sendiri telah mengklaim seluruh wilayah Laut Cina Selatan seluas $2000.000 \mathrm{~km}^{2}$ atau $90 \%$ dimana laut Natuna Utara masuk dalam klaim tersebut.

\section{Traditional Fishing Ground Menurut UNCLOS 1982}

Pemerintah Cina mengatakan bahwa mereka memasuki wilayah ZEEI karena melakukan Traditional Fishing Ground, Cina melakukan kegiatan ini dengan berdasarkan sejarah kuno yang telah mereka yakini dari abad ke 2 sebelum masehi. Konsep Traditional Fishing Grounds yang dimaksud adalah:

"The term 'historic rights' maybe defined as rights over certain land or maritime areas acquired by a state through a continuous and public usage from time immemorial and acquiessence by other states, although those rights would not normally accrue to it under general international law."23

Maksud dari konsep tersebut syarat-syarat untuk diakuinya hak tersebut adalah penggunaan secara turun temurun dan

22 Akbar Kurnia Putra, Hak Lintas Damai Right Of Innocent Passage Berdasarkan United Nations Convention On The Law Of The Sea 198. Jurnal Ilmu Hukum, Vol. 7, No. 2. hal. 27.

23 Satria Unggul Wicaksana Prakasa dan Al QodarPurwo. Analisis Historical Traditional fishing Right Pada Zona Ekonomi Eksklusif Indonesia. Legality. Vol. 27, No. 1. hal. 90.

Uti Possidetis: Journal of International Law, Vol. 1, No. 3 (2020) 
berkelanjutan yang tidak lekang oleh waktu, bahkan sebelum UNCLOS 1982 disepakati sebagai rule based system dari hukum laut internasional yang juga mengakomodir adanya pembagian wilayah laut dalam pengaturannya.

Apabila dikaji Didalam hukum laut Internasional pada UNCLOS 1982 hukum tersebut tidak pernah mengatur mengenai traditional fishing ground, melainkan UNCLOS 1982 mengatur mengenai traditional fishing rights. Tradisional fishing rights diatur pada pasal 51 ayat 1 menyatakan :

"Without prejudice to article 49, an archipelagic State shall respect existing agreements with other States and shall recognize traditional fishing rights and other legitimate activities of the immediately adjacent neighbouringWithout prejudice to article 49, an archipelagic State shall respect existing agreements with other States and shall recognize traditional fishing rights and other legitimate activities of the immediately adjacent neighbouring States in certain areas falling within archipelagic waters. The terms and conditions for the exercise of such rights and activities, including the nature, the extent and the areas to which they apply, shall, at the request of any of the States concerned, be regulated by bilateral agreements between them. Such rights shall not be transferred to or shared with third States or their nationals. States in certain areas falling within archipelagic waters. The terms and conditions for the exercise of such rights and activities, including the nature, the extent and the areas to which they apply, shall, at the request of any of the States concerned, be regulated by bilateral agreements between them. Such rights shall not be transferred to or shared with third States or their nationals."

Mengenai potensi untuk berurusan dengan negara pantai yang lain Traditional Fishing Rights juga diatur pada pasal 47 ayat 6 UNCLOS 1982 yang menyatakan : 
"If a part of the archipelagic waters of an archipelagic State lies between two parts of an immediately adjacent neighbouring State, existing rights and all other legitimate interests which the latter State has traditionally exercised in such waters and all rights stipulated by agreement between thoseStates shall continue and be respected." 24

Pasal 47 ayat 6 UNCLOS 1982 menyatakan bahwa negara kepulauan yang bertetangga atau langsung berdampingan wajib kiranya untuk membuat perjanjian bilateral diantara kedua Negara pantai. Klaim Cina mengenai daerah kegiatan perairan Cina di zona ekonomi eksklusif Indonesia yang berdasarkan Traditional Fishing Grounds di laut Natuna Utara bersifat unilateral dan klaim tersebut salah, karena UNCLOS 1982 hanya mengenal Traditioal Fishing Rights.

Dari uraian diatas dapat disimpulkan bahwa dalam hukum laut internasional atau UNCLOS 1982 tidak mengatur mengenai traditional fishing ground melainkan UNCLOS 1982 hanya mengatur mengenai Traditional Fishing Rights, bahkan untuk melakukan kegiatan Traditional Fishing Rights harus ada perjanjian bilateral, sementara Indonesia tidak pernah melakukan perjajian tersebut dengan Cina, namun Indonesia melakukan perjanjian biletral kepada negara tetangga yaitu Malaysia. Berarti Klaim nine-dash line dan kegiatan traditional fishing ground Cina tidaklah Relevan menurut UNCLOS 1982.

\section{Sikap Indonesia Terhadap Klaim Negara Cina di Laut Natuna Utara}

Dalam perspektif Indonesia, apa yang dilakukan oleh Cina dalam mengklaim nine-dash line di Zona Ekonomi Eksklusif Indonesia tentunya dapat mengganggu stabilitas keamanan negara Indonesia, selama ini dari beberapa konflik Cina

24 Pasal 47 ayat 6 United Nations Conventions On The Law Of The Sea 1982.

Uti Possidetis: Journal of International Law, Vol. 1, No. 3 (2020) 
terhadap beberapa negara di perbatasan laut Cina Selatan justru Indonesia tidak pernah ikut campur karena Indonesia tidak pernah bermasalah dengan Cina terkait sengketa wilayah di Laut Cina Selatan.

Sikap pertama ialah bahwa wilayah Indonesia merupakan wilayah yang ditetapkan dengan ketentuan UNCLOS 1982, maka dari itu untuk mempertegas kedaulatan negara Republik Indonesia Berdasarkan putusan mahkamah internasional melalui mahkamah arbitrase internasional pada bulan juli 2016 mengganti nama laut Natuna Utara. Dasar negara Indonesia mengganti nama laut Natuna Utara adalah sebagai berikut:

1. Pengakuan Indonesia sebagai negara kepulauan dalam United Nations Conventions On The Law of The Sea 1982 yang menegaskan hak-hak Indonesia Dalam menentukan batas-batas dan menamai wilayah lautnya.

2. Penamaan laut Natuna Utara dilakukan diwilayah Yurisdiksi laut Indonesia.

3. Penamaan Laut Natuna Utara merupakan bagian dari upaya Indonesia untuk mempertegas kedaulatan atas wilayah laut di Utara Natuna.

Pemerintah Indonesia melalui Menteri Luar Negeri Retno Marsudi juga telah memanggil perwakilan Cina Sun Weide yang dalam hal ini adalah Kuasa Usaha Sementara Kedutaan Besar Cina di Jakarta, untuk menyampaikan Nota Protes Diplomatik atas persoalan klaim Nine-dash Line tersebut, yakni :

a. Terkait masalah pelanggaran hak berdaulat dan yuridiksi Indonesia di Kawasan ZEE dan landas kontinen;

b. Protes upaya yang dilakukan oleh Kapal Coast Guard Cina untuk mencegah upaya penegakan 
hukum yang dilakukan otoritas Indonesia di wilayah ZEE dan landas kontinen;

c. Protes adanya pelanggaran terhadap kedaulatan laut territorial Indonesia.

Sikap kedua Indonesia adalah negara Cina dan Indonesia sama-sama merupakan negara anggota peserta UNCLOS 1982 makadari itu Republik Indonesia mengambil sikap dengan cara mengajak Cina agar menghormati, implementasi dari hukum laut internasional. kemudian Indonesia tidak akan pernah mengakui nine-dash line atau sembilan garis putus-putus, karena klaim yang dilakukan oleh Cina ini tidak diakui oleh hukum baik itu hukum nasional maupun hukum internasional yakni UNCLOS 1982 untuk Indonesia tidak akan membawa kasus sengketa ini seperti yang dilakukan oleh negara Philipina ke PCA, karena Indonesia menganggap tidak punya sengketa wilayah atau sengketa apapun dengan Cina.

\section{Penutup}

Berdasarkan pembahsan diatas, maka artikel ini menyimpulkan bahwa Klaim nine-dash line oleh Cina atas laut natuna utara merupakan klaim sembilan garis putus-putus yang dibuatsecarasepihak oleh negara Cina di laut Cina Selatan, klaim nine-dash line ini berdasarkan fakta sejarah kuno Cina jauh sebelum adanya UNCLOS 1982, klaim ini secara turun temurun yang diyakini oleh masyarakat Cina sejak masa lampau pada abad ke 2 sebelum Masehi, Hanya saja sebagai negara yang sama-sama meratifikasi UNCLOS 1982 klaim Cina terhadap nine-dash line tidak relevan atau tidak sesuai dengan ketentuan UNCLOS 1982, karena pada pasal 47 ayat 6 UNCLOS 1982 hanya mengatur mengenai Traditional Fishing Rights, bahkan untuk melakukan Traditional Fishing Rights harus ada perjanjian bilateral sementara Indonesia tidak punya perjanjian bilateral kepada Cina. Dikaji dalam hukum 
laut internasional apa yang dilakukan oleh Cina melanggar Pasal 3 UNCLOS 1982 karena batas laut territorial di setiap negara telah diatur dalam konvensi tersebut adalah 12 mil, sedangkan Klaim Cina atas ZEE Indonesia di Laut Natuna seluas $50.000 \mathrm{~km} 2$ tentunya sudah mengganggu wilayah kedaulatan Indonesia di lautNatuna Utara.

Artikel ini juga menyimpulkan bahwa sikap Indonesia terhadap klaim Nine-dash line Negara Cina di Laut Natuna Utara terutama Indonesia mengganti nama Laut Cina Selatan menjadi laut Natuna Utara yang Berdasarkan putusan mahkamah internasional melalui mahkamah arbitrase internasional pada bulan juli 2016, penamaan laut Natuna Utara sesuai dengan konvensi PBB tentang hukum laut (UNCLOS 1982). Indonesia tidak akan pernah mengakui klaim nine-dash line karena klaim sepihak yang telah dilakukan oleh Cina ini tidak memiliki alasan hukum yang diakui oleh UNCLOS 1982. Maka dari itu Indonesia mengganggap sama sekali tidak mempunyai sengketa apapun dengan Cina terkhusus sengketa wilayah.

\section{Referensi}

\section{Instrument Hukum}

United Nations Conventions On The Law Of The Sea 1982. Undang-Undang Nomor 5 Tahun 1983 tentang Zona Ekonomi Eksklusif Indonesia.

Undang-Undang Nomor 17 Tahun 1985 tentang Tentang Pengesahan United Nations Convention On The Law Of The Sea.

The South Cina Sea Arbitration Award About The Republic of Philippines v. The People's Republic of China.

\section{Buku}


Adolf, Huala. Hukum Penyelesaian Sengketa Internasional. Penerbit Sinar Grafika. Jakarta. 2016.

Campbell, Henry Black. Black's Law Dictionary. Fourth Edition.

Minnesouta : West Publlishing Co. 1968.

Huda, Ni'matul. Ilmu Negara. Penerbit Raja Wali Pers. Jakarta. 2014.

Marzuki, Peter Mahmud. Penelitian Hukum. Penerbit Kencana. Jakarta. 2008.

\section{Artikel/Jurnal}

Deni, Fitra dan Sari, Lukman. Upaya Diplomasi Indonesia Terhadap Klaim Cina Atas Zona Ekonomi Eksklusif Indonesia Di Laut Natuna Utara. International \& Diplomacy, Vol. 3. No. 1. hal. 5

Junef, Muhar. Sengketa Wilayah Maritim Di Laut Tiongkok Selatan Maritime Territorial Dispute in South Cina Sea. De Jure. Vol. 18. No. 2.

Prakasa, Satria Unggul Wicaksana dan Purwo, Al Qodar. Analisis Historical Traditional fishing Right Pada Zona Ekonomi Eksklusif Indonesia. Legality. Vol. 27, No. 1.

Putra, Akbar Kurnia. Hak Lintas Damai Right Of Innocent Passage Berdasarkan United Nations Convention On The Law Of The Sea 1982". Jurnal Ilmu Hukum, Vol. 7, No. 2.

Sambago, Alief. Penamaan Laut Natuna Utara Oleh Pemerintah Indonesia Dalam Perspektif Hukum Internasional. Jurist-Diction. Vol.1 No. 2.

\section{Laman}

Pemerintahan Kabupaen Natuna. https://natuna kab.go.id/sel ayang -panadang- kabupaten -natuna -provinsikepulauan -riau/. Diakses pada tanggal 13 Juni 2020.

Foreign Ministry Spokesperson Lu Kang's Remarks on Statement by Spokesperson of US State Department on 
South Cina Sea Arbitration Ruling, https://www.fm prc.gov.cn/nanhai/eng/fyrbt 1/t1380409.htm. DiaksespadaTanggal 21 Oktober 2020. Diakses pada tanggal 13 Juni 2020

Batamnews, https://www.batamnew s.co.id/berita-141168mengenal-9-garis-putus putus-tiongkok-dan-klaimCina-selatan.html. Diakses pada tanggal 21 Agustus 2020. 